Abstracta Iranica Abstracta Iranica

Revue bibliographique pour le domaine irano-aryen

Volume 25 | 2004

Comptes rendus des publications de 2002

\title{
Hošūnat, zanān va eslām. Essen, Nīmā, 1381/2002, 158 p. [La violence, les femmes et l'Islam]
}

\section{Robert Mallet}

\section{(2) OpenEdition}

Journals

\section{Édition électronique}

URL : http://journals.openedition.org/abstractairanica/5139

DOI : 10.4000/abstractairanica.5139

ISSN : 1961-960X

Éditeur :

CNRS (UMR 7528 Mondes iraniens et indiens), Éditions de l'IFRI

\section{Édition imprimée}

Date de publication : 15 mai 2004

ISSN : 0240-8910

\section{Référence électronique}

Robert Mallet, « Hošūnat, zanān va eslām. Essen, Nimāā, 1381/2002, 158 p. [La violence, les femmes et I'Islam] », Abstracta Iranica [En ligne], Volume 25 | 2004, document 319, mis en ligne le 15 mars 2006, consulté le 25 septembre 2020. URL : http://journals.openedition.org/abstractairanica/5139; DOI : https://doi.org/10.4000/abstractairanica.5139

Ce document a été généré automatiquement le 25 septembre 2020.

Tous droits réservés 


\title{
Hošūunat, zanān va eslām. Essen, Nīmā, $1381 / 2002,158$ p. [La violence, les femmes et l'Islam]
}

\author{
Robert Mallet
}

1 Il s'agit d'un petit livre dont l'ambition est à la fois historique et anthropologique. L'auteur a choisi, comme sujet d'études, tout d'abord la violence politique traitée dans une première partie, puis, dans une deuxième partie, la violence envers les femmes. Elle s'efforce, ainsi de démontrer, par des récits historiques et différents extraits de textes que cette violence systématique face à l'altérité fait partie intégrante de la pensée islamique et en particulier de son histoire politique. Pour l'A., les différentes formes de «violence " présentes dans les faits historiques, - actes terroristes comme celui de 11 septembre 2001 et même "faits divers" dont les protagonistes sont musulmans - sont identiques et trouvent leurs bases théoriques et leurs sources de motivations dans les textes et les lois islamiques d'origine.

2 En rejetant toutes les possibilités de réformes proposées par les intellectuels tel que Šarīatīi, Ṭāleqānī, Sorūšs, etc., l'auteur nous décrit un islam violent, sanglant, archaïque, étriqué et incompatible à la moindre modernité.

3 Écrit dans un style texte militant, à partir de sources pour la plupart de deuxième main, ce livre, avec de profondes lacunes méthodologiques, ignore aussi toute définition basique de la notion de "violence » en tant que sujet historique, anthropologique ou sociologique. Dans un anachronisme total, elle confond les normes et les périodes historiques et fait intervenir des données peu fiables afin d'atteindre son objectif anticlérical et nationaliste.

4 Le seul point positif de ce livre est le choix d'étudier « la violence ", peu traitée jusque maintenant dans les travaux concernant l'Iran. 
INDEX

Thèmes : 13.1. Iran

nompropre Sharīatīi, Tāleqānī, Sorūsh

\section{AUTEURS}

ROBERT MALLET

Paris 